\title{
Constructions, their families and their neighborhoods: the case of durak durakom 'a fool times two'
}

\author{
Конструкции, их семьи и соседи: «Дурак дураком»
}

\author{
Laura A. Janda ${ }^{1} \cdot$ Mihail Kopotev $^{2}$ - Tore Nesset ${ }^{1}$
}

Published online: 20 July 2020

(C) The Author(s) 2020

\begin{abstract}
On the basis of data from the Russian National Corpus, we analyze the meanings and structure of the syntactic construction observed in phrases like durak durakom 'fool-NOM.sG fool-INS.SG', which we term the 'NOM INS construction'. We argue that the construction constitutes a network of three closely related subcategories, which we refer to as 'Extreme', 'Paragon' and 'Discourse Change'. It is furthermore shown that a diachronic change has taken place, whereby Discourse Change has overtaken Extreme as the dominant subcategory. Our analysis provides ample evidence for the main tenets of Construction Grammar, namely that a language is a network of related constructions, that meaning is often not compositional, that there is a continuum from idiomatic to schematic uses of constructions, and that constructions evolve over time.
\end{abstract}

Аннотация В статье на основе Национального корпуса русского языка анализируются значение и структура синтаксической конструкции типа 'Дурак дураком', которую мы для краткости обозначаем 'NOM INS'. Мы показываем, что указанная конструкция представляет собой радиальную категорию, состоящую из трёх взаимосвязанных подтипов, которые в соответствии с их значением можно назвать 'экстремальный' ('Extreme'), 'образцовый' ('Paragon') и 'смена дискурса' ('Discourse Change'). В статье показано, что в процессе диахронического развития подтип со значением 'смена

The research for this paper was financially supported by the Russian Science Foundation, project "Structures with lexical repetitions from the viewpoint of contemporary linguistic theories" No. 19-78-10048 based at St Petersburg State University; part of the research was made possible through a HUMEVAL grant from the Norwegian Research Council.

\begin{tabular}{l}
\hline T. Nesset \\
tore.nesset@uit.no \\
L.A. Janda \\
laura.janda@uit.no \\
M. Kopotev \\
mihail.kopotev@ helsinki.fi \\
$1 \quad$ UiT The Arctic University of Norway, Troms $\emptyset$, Norway \\
$2 \quad$ Saint-Petersburg State University, Saint-Petersburg, Russia
\end{tabular}


дискурса' обгоняет 'экстремальный' подтип по количеству употреблений и становится доминирующим в современном русском языке. Предложенный в статье анализ подтверждает основные теоретические установки Грамматики конструкций, а именно: а) язык представляет собой сеть связанных между собой конструкций, значение которых часто оказывается некомпозициональным; б) конструкции образуют континуум от идиоматичных до композициональных вариантов употребления; в) конструкции и вся сетевая структура изменяются с течением времени.

\section{Introduction}

In recent years Construction Grammar has established itself as a major linguistic framework, and the traditional term 'construction', understood as a conventionalized pairing of form and meaning, has experienced a renaissance in theoretical linguistics (Goldberg 1995, 2005). We analyze the Russian syntactic construction instantiated by the phrase durak durakom [foolNOM.SG fool-INS.SG] in the three examples (1)-(3) cited here. ${ }^{1}$ While these examples are in many ways quite similar, some semantic differences can also be discerned. In none of these examples can the meaning of the construction be said to be compositional since it cannot be derived from the repetition of $d u r a k$ 'fool' in two different grammatical cases, the nominative and the instrumental. In example (1), the construction conveys a maximum magnitude for the meaning of the noun durak. Here the Speaker is chastising his Addressee for being the ultimate fool imaginable. We can term the meaning of the construction here as 'Extreme':

(1) Extreme

A to ty teper' durak durakom, xuže morkovki na Lune, a ja i vovse trupom ležu, červej ždu ....

'Otherwise you're now an absolute fool, more useless than a carrot on the Moon, and I'm lying here like a corpse, waiting for the worms...'

(Ju. Bujda. U koški devjat' smertej (2000). Novyj Mir. 2005) ${ }^{2}$

The import of example (2) is considerably milder. We are not dealing with a maximal degree of foolishness, but rather a normal (average) degree of the property. The subject is just an ordinary fool, nothing special. Since this fool is just a perfect example of a fool rather than an extreme case, we can term this meaning as 'Paragon'. Very often, the paragon type involves a comparison in which two things are claimed to be similar:

\section{Paragon}

Krasivej mužčiny vo vsej gubernii net, umnyj, bogatyj, a nikakogo tolku ... Durak durakom ...

'There isn't a more handsome man in the whole province; he is clever and wealthy, but he just doesn't understand ... An ordinary fool.' $\quad$ (A. P. Čexov. Lešij. 1890)

In example (3), the construction has a discourse function. The speaker first acknowledges what the discourse participants have already established, namely that they consider the accountant Mečetkin a fool. The speaker then uses this acknowledgement to set the stage for an

\footnotetext{
${ }^{1}$ We will not discuss the question as to whether examples (1)-(3) represent instances of one construction or three different constructions, since this question is tangential to our research, which focuses on the meanings of and relationships between the three (sub)categories illustrated in (1)-(3).

${ }^{2}$ All numbered examples except the variants b-f in (4), are extracted from the Russian National Corpus (ruscorpora.ru).
} 
attempt to redirect attention to something that she considers to be more important: the fact that Mečetkin has a point. Here the construction signals a sudden shift in the discourse that we can term 'Discourse change'. Typically, the noun in the instrumental is followed by the conjunctions $a$ 'but' or no 'but', which provide a concessive nuance: although Mečetkin may be a fool, on this occasion he provides sound advice:

(3) Discourse Change

Durak durakom, a delo govorit.

'Ok, he's a fool, but he talks business.'

(A. Vampilov. Prošlym letom v Čulimske. 1971)

Because there are almost no constraints on what lexemes can appear in this construction, we call it the 'NOM INS construction', using the Leipzig glossing (2015) standard abbreviations $^{3}$ for the nominative and instrumental case that characterize this construction, separated by a tilde to indicate repetition. ${ }^{4}$ We use the term 'instantiation' (Langacker 2008, p. 17) to refer to a specific lexified version of the NOM $\sim$ INS construction, so durak durakom is an instantiation of the construction with the lexeme durak as its filler.

The NOM INS construction has a number of curious properties in terms of its meaning, its syntactic structure, and its relationships to other constructions, all of which are addressed in more detail below. The range of phenomena connected with this construction shed important light on the networks of semantic and syntactic influences that impact syntactic constructions in Russian in particular and in language in general.

The structure of the NOM $\sim$ INS construction is peculiar for Russian. It resembles grammatical patterns that are impossible or marginal in the language. On the one hand it resembles a copula construction with a nominative subject and a predicate in the instrumental case. Whereas predicate noun phrases can be marked by the instrumental case in Russian, this normally requires an overt copula verb. Example (4a) has the overt copula byl 'was' and the instrumental noun indicating Uncle Kostja's profession. It is possible to use a copula verb in all three tenses, thus in addition to past tense in (4a), also present tense in (4b) and future tense in $(4 \mathrm{c})$, all the while preserving the instrumental case in the predicate. However, the construction with the zero-copula and the instrumental case in (4d) is not grammatical in modern Russian. This construction is attested in earlier stages of the language until the eighteenth century (cf. Moser 1994, pp. 67-68). There are exceptions in the case of idioms (cf. Nichols 1981, p. 208) and, at least for some speakers, the use of the instrumental becomes grammatical when modified (cf. Mrazek 1964, pp. 235-237; Mathiassen 1996, p. 231) as in (4e). ${ }^{5}$ Aside from these exceptions, we must change the predicate in (4d) to the nominative case in order to produce a grammatical sentence, as in (4f):

(4) Variants of copula constructions in Russian:

a. Djadja Kostja byl učenym-filologom.

'Uncle Kostja was a language and literature scholar.'

(A. Zajcev. Brat'ja. Tramvaj. 1990)

b. Djadja Kostja javljaetsja učenym-filologom.

'Uncle Kostja is a language scholar.'

\footnotetext{
${ }^{3}$ Available at: https://www.eva.mpg.de/lingua/resources/glossing-rules.php.

${ }^{4}$ There appear to be few constraints on what nouns can occur in the NOM INS construction, though indeclinable nouns like kofe 'coffee' and pal'to 'coat' seem to be blocked, since such nouns cannot show the difference between the nominative and instrumental cases.

${ }^{5}$ Example (4e) is also acceptable under ellipsis, where the context supplies an implicit verb, such as rabotat' 'work'.
} 
c. Djadja Kostja budet učenym-filologom.

'Uncle Kostja will be a language scholar.'

d.*Djadja Kostja učenym-filologom.

'Uncle Kostja is a language scholar.'

e. Djadja Kostja v universitete učenym-filologom.

'Uncle Kostja is a language scholar at the university.'

f. Djadja Kostja-učenyj-filolog.

'Uncle Kostja is a language scholar.'

On the other hand, the NOM INS construction resembles a construction in which one noun is described by a second noun in the instrumental case, and this description usually evokes an iconic metaphor, as in kepka blinom 'a cap (shaped) like a pancake' (as in a beret or baseball cap) and usy kolečkom 'mustache in a curlicue' (à la Salvador Dalí). This use of the instrumental case is described by Janda (1993) as a version of the 'Label' meaning of the case (also present in the copula construction), in which the instrumental case refers to a category of things that the noun in the nominative belongs to.

However, neither the copula construction nor the Label construction make use of repetition, which is a hallmark of the NOM INS construction. And while both the copula construction and the use of the instrumental case to signal a Label have received considerable attention in the scholarly literature, the same cannot be said for the NOM INS construction, which has heretofore been mentioned only in passing (Nichols 1981; Veličko 2016).

Our approach to the NOM INS construction is one based on a Construction Grammar perspective (Goldberg 1995, 2005; Croft 2001; Fried and Östman 2004; Diessel 2015). The main tenet of Construction Grammar is that constructions are language-specific formmeaning pairings available at all levels of linguistic complexity. Furthermore, Construction Grammar: a) views language as a network of related constructions, b) recognizes that meaning is often complex and not compositional, c) recognizes that constructions range along a continuum from idiomatic (which at their extreme might be lexicalized or behave as unanalyzed 'chunks') to schematic, and d) acknowledges that constructions can evolve and change over time. The NOM INS construction amply illustrates all of these phenomena, and therefore this construction and Construction Grammar are a perfect fit: the theoretical framework is appropriate for describing of the NOM $\sim$ INS construction, and the NOM $\sim$ INS construction presents a challenging testing ground for the framework of Construction Grammar.

Construction Grammar is a branch of cognitive linguistics, which is a usage-based theoretical approach to language. This means that language usage (as opposed to underlying forms or internal language) is the primary object of study, and therefore generalizations should emerge from analysis of usage data. For this reason, we use corpus data to investigate the NOM $\sim$ INS construction.

In Sect. 2 we describe the database upon which the remainder of the article is based, explaining how it was obtained and detailing some global findings. Section 3 presents a radial category of the subtypes of the NOM $\sim$ INS construction, including the three mentioned above, plus one more that combines the characteristics of Extreme and Discourse Change. We explore the meanings and relationships among the subtypes in some detail. Taken together, the subtypes in this radial category structure the core of the NOM $\sim$ INS construction. In the subsequent two Sects. 4 and 5 we examine the relationships between the NOM INS construction and other constructions in Russian, focusing first on relationships based on an intensifying meaning, and then on relationships based on reduplication. In each instance we find a closely related construction that could be considered part of the periphery of the NOM INS construction. A historical perspective is taken in Sect. 6, in which we see that the center of gravity of the NOM INS construction has shifted from Extreme to Discourse 
Change. We conclude in Sect. 7 with a representation of the structure of the NOM INS construction and its relationships to peripheral constructions as well as both intensifying and reduplication constructions in Russian.

\section{Our dataset}

Data was collected in 2019 from the main part of the Russian National Corpus (ruscorpora.ru, henceforth RNC), which at the time comprised approximately 288 million words representing the years 1800-2018. In order to collect the relevant data, searches were defined as follows:

a* S,nom,sg, distance: 1 from a* S,ins,sg lexred

meaning that we searched for a noun (S) marked nominative (nom) singular (sg) and beginning with a ( $\mathrm{a}^{*}$, where $*$ is a wildcard, meaning that any string may follow), immediately followed (distance: 1 from) by another noun marked instrumental (ins) singular (this search allows intervening punctuation, such as a hyphen), with the further stipulation that there should be lexical reduplication (lexred). This type of search was carried out for all letters of the Russian alphabet (except $b$ and 6 ) and then also repeated substituting 'pl' (plural) for 'sg' in order to maximize data collection. After cleaning to remove duplicate examples and irrelevant noise, this process yielded 2573 examples containing singular nouns and 515 examples containing plural nouns, for a total of 3088 examples.

A major source of noise (over 500 examples) is drug drugom, the Russian equivalent of English 'each other' in contexts requiring the instrumental case (cf. Knjazev 2007), as in example (5):

(5) Oni dopili i kon'jak, speli neskol'ko pesen i rasstalis', vpolne dovol'nye drug drugom. 'They drank up the cognac, sang several songs and parted entirely satisfied with each other.'

(D. Koreckij. Menty ne angely, no... . 2011)

Such examples are excluded from further consideration on the grounds that: a) drug behaves as a pronoun, not as a noun in this construction, b) drug drugom is merely one member of a larger paradigm including all non-nominative cases and elaborated by a potentially large set of prepositions (as in drug $s$ drugom 'with each other', drug $k$ drugu 'to each other'), and c) the use of the instrumental is always directly governed by another word (by dovol'nye 'satisfied' in (5)) rather than being inherent to the construction. However, drug drugom presents a robust NOM $\sim$ INS pattern in the language, since it is found at the rate of almost two occurrences (1.94) per million words in the RNC. This fact is in itself significant in that it lends support to the existence of similar structures such as that of our NOM $\sim$ INS construction. ${ }^{6}$

Our entire database of the NOM $\sim$ INS construction has been hand-annotated for the semantics of the subtype, the semantic classes of the nouns, and the verbal government pattern, and this database is publicly accessible from the Troms $\emptyset$ Repository of Language and Linguistics archive at https://doi.org/10.18710/ZAM96S. The semantics of subtypes are the topic of Sects. 3 and 4, while characteristics of the database in terms of the nouns and verbs that the NOM INS construction is associated with are detailed in the remainder of the present section.

\footnotetext{
${ }^{6}$ Another robust NOM INS pattern that deserves mention is samo soboj 'it goes without saying'. However, samo soboj does not involve repetition of the same lexical item, and thus differs from the construction under scrutiny in the present study.
} 


\subsection{Nouns, lexicalized types, productivity}

The Pearson correlation between the frequency of individual noun lexemes in our database and their overall frequency in the RNC is very low: 0.056. This indicates that the distribution of nouns in the NOM $\sim$ INS construction is very different from that of the corpus as a whole. In other words, the NOM $\sim$ INS construction strongly selects the nouns that fill its slots: a few nouns are much more likely to appear in this construction than most other nouns. An automatically generated semantic network of nouns in the NOM INS construction in our database displays high density, confirming the results of the Pearson correlation that there are certain nouns that are strongly associated with the construction. For this purpose, we used a word2vec distributional semantic model trained on the RNC data and available on rusvectores.org.

The meanings of the nouns that are attracted to the NOM INS construction play an important role in relation to the meaning of the construction. Most often we observe a metonymic relationship between the noun and the construction in that a salient feature of the referent of the noun is the focus of the meaning of the construction. In other words, the most salient feature of durak 'fool' is foolishness, which is emphasized in the meaning of the construction.

Some instantiations of the NOM INS construction are very frequent, to the point that they serve as idiomatic expressions. Table 1 displays candidates for idiomatic expressions arranged according to their frequency in our database. Only the gloss of the repeated lexeme is listed because the meaning of the expression can vary for some of these lexemes (as demonstrated in examples (1)-(3) above). The column marked 'Main Subtype' lists the subtype most frequently associated with this lexeme.

Two of the top five, čest' čest'ju and čin činom, are nearly synonymous idioms, meaning 'properly', and fixed to the point that they are arguably adverbs, as illustrated in (6) and (7) in which they could be substituted by adverbs such as pravil'no 'properly':

(6) Čest' čest'ju 'properly'

Otec sdelal vse čest' čest'ju i rasproščalsja so svoimi roditeljami teper' uže navsegda. 'Father did everything properly and has now said farewell to his parents forever.'

(A. Rybakov. Tjaželyj pesok. 1975-1977)

Table 1 High frequency NOM INS collocations

\begin{tabular}{llll}
\hline NOM INS & Gloss of filler lexeme & Main Subtype & Freq \\
\hline čest' čest'ju & 'honor' & Extreme & 338 \\
durak durakom & 'fool' & Extreme & 128 \\
klin klinom & 'wedge' & Instrument & 90 \\
družba družboj & 'friendship' & Discourse Change & 80 \\
čin činom & 'rank' & Extreme & 75 \\
dura duroj & 'fool' & Extreme & 51 \\
delo delom & 'job' & Discourse Change & 39 \\
tuča tučej & 'rain cloud' & Extreme & 37 \\
služba služboj & 'service' & Discourse Change & 36 \\
zver' zverem & 'beast' & Extreme & 28 \\
ljubov' ljubov'ju & 'love' & Discourse Change & 23 \\
molodec molodcom & 'clever / healthy person' & Extreme & 23 \\
vojna vojnoj & 'war' & Discourse Change & 20 \\
\hline
\end{tabular}


(7)

Čin činom 'properly'

Naš xrabrec lovil špionov, obyskival spekuljantov, vse šlo čin činom.

'Our hero caught spies and conducted searches of black marketeers, everything was done properly.'

(A. I. Aldan-Semenov. Krasnye i belye . 1966-1973)

A third expression that might be analyzed as an adverb is tuča tučej, which can be translated roughly as 'in a very bad mood', as in (8):

(8) Kol'cov priexal za dve minuty do vzleta, tuča tučej i, ni na kogo ne gljadja i ni s kem ne zdorovajas', prošestvoval v pervyj salon.

'Kol'cov arrived two minutes before takeoff, in a very bad mood, and, without looking anyone in the eye or saying hello, proceeded into the first-class cabin.'

(T. Ustinova. Personal'nyj angel. 2002)

Of high frequency expressions that are associated primarily with the Extreme subtype, the remainder all refer to human beings who are either strongly labeled as fools (durak, dura), beasts (zver', a metaphorical use) or clever people (molodec).

Also strongly lexicalized is the idiomatic expression klin klinom, literally 'wedge by means of a wedge' with a meaning close to '(fight) fire with fire'. Although this expression is often associated with the verbs vybivat' and vyšibat', both meaning 'knock out' (in which case the first noun is accusative rather than nominative), klin klinom also appears independent of these verbs, acting like an adverb meaning something like 'in a tough way', as illustrated in (9):

(9) [...] vo-vtoryx, nado pokazat', čto ničego takogo ne proizošlo i vovse Marusja ne stesnjaetsja. Klin klinom, koroče.

'[...] secondly, it must be shown that nothing of the kind happened and that Marusja is not shy at all. She can beat them at their own game, in short.'

(P. Vološina and E. Kul'kov. Marusja. 2009)

We term this the 'Instrument' subtype and include it in this study as a peripheral subtype. This Instrument subtype is productive with other nouns and has a complicated relationship with the rest of the subtypes that is discussed in more detail in Sect. 5.

The remaining high frequency expressions are associated with Discourse Change, and frequently also with each other by means of an extension of the construction to 'NOM $\sim$ INS, $a$ / no NOM $\sim$ INS', in which two different instantiations of the NOM $\sim$ INS construction are connected by a conjunction. Thirty of our examples contain družba družboj, a služba služboj 'friendship is friendship, but service is service', a phrase commonly used when the speaker wants to shift the discourse away from friendly chit-chat and get to work, or wishes to say that $\mathrm{s} / \mathrm{h}$ must stick to the rules despite the fact that $\mathrm{s} / \mathrm{he}$ is on friendly terms with the addressee. The entrenchment of this phrase is additionally supported by rhyme (similar to the way that alliteration is known to support idioms in English, cf. Gries 2011). Similarly, we also find examples of družba družboj, a delo delom 'friendship is friendship, but business is business'; ljubov' ljubov'ju, a delo delom 'love is love, but business is business'; and šutki šutkami, a delo delom 'jokes aside, but business is business', all with approximately the same discourse function, namely of saying "ok, but now we have to focus on work".

However, continuations with phrases other than a second NOM $\sim$ INS are also common, as in (10) and (11):

(10) - A mama utverždaet, čto ljubov' ljubov'ju, no nado uznat' čeloveka, a dlja ètogo nužno vremja.

'Mother however claims that while love is important, one has to get to know a person, and that takes time.'

(V. Černyx. Moskva slezam ne verit. 1980) 
(11) Vojna vojnoj, no krasota prirody nikuda ne isčezala.

'There may be a war going on, but the beauty of nature has not disappeared.'

(I. K. Arxipova. Muzyka žizni. 1996)

As mentioned in Sect. 1, practically all nouns are possible in the NOM INS construction, and it therefore comes as no surprise that nouns that are strongly attracted to the NOM INS construction cover a wide spectrum, including words denoting: a) human beings, particularly (but by no means exclusively) words that deride their intelligence, such as durak / duračok '(male) fool', dura / duročka '(female) fool', idiot 'idiot', bolvan 'blockhead', see (1)-(3) above; b) animals, often used metaphorically to deride human beings, such as zver' 'animal', medved' 'bear', and byk 'bull', see (12); c) concrete objects such as mešok 'bag', kniga 'book', komp'juter 'computer', see (13), including objects that can be used metaphorically to refer to people brevno 'log', pen' 'stump', peč' 'stove', see (14); d) substances like vozdux 'air', eda 'food', trava 'grass', čaj 'tea', see (15); and e) abstractions such as gore 'woe', demokratija 'democracy', and iskusstvo 'art', see (16):

(12) On na nee kak gljanul, vsja roža buroj kroviščej nalilas', zver' zverem sdelalsja!

'He looked at her, and blood rushed to his whole face turning it scarlet, he was like a vicious beast!'

(F. Knorre. Kamennyj venok. 1973)

(13) Vse-taki komp'juter komp'juterom, a bez real'noj žizni tože ploxo.

'After all a computer is good, but things are also bad without a real life.'

(Pokolenie.ru: novaja «Faza» (2002). Kul'tura. 2002.04.01)

(14) Ležiš' brevno brevnom, i ničego ne čuvstvueš’...

'You're lying there like a bump on a log, not feeling anything ...'

(V. Rybakov. Xroniki smutnogo vremeni. 1998)

(15) - A bez nix čto mjaso, čto ryba - trava travoj.

'But without them [salt and pepper] both meat and fish are as bland as grass.'

(B. Možaev. Živoj. 1964-1965)

(16) Iskusstvo iskusstvom, a sem'ju kormit' nado.

'Art has its value, but one has to feed one's family.'

(I. Pivovarova. Odnaždy Katja s Manečkoj. 1986)

In principle, any noun can appear in the NOM INS construction, and it is clearly productive as we see with modern loanwords, such as komp'juter in example (13) above and margarin 'margarine' in example (17). Example (18) further shows that the NOM INS construction can even be filled with proper nouns such as Darvin 'Darwin', Moskva 'Moscow', Anglija 'England':

(17) devčonki, a nikto ne pokupaet šokoladnoe maslo? Pomnju, v detstve ja ego očen' ljubila, a sejčas kak-to raz kupila-margarin-margarinom s kakao i saxarom, a xočetsja vkusnogo.

'Hey girls, does anyone buy chocolate butter? I remember that I used to love it as a child, but I bought it again recently-it was the blandest margarine mixed with cocoa and sugar, not tasty like it should be.'

(kollektivnyj. Forum: Kakoe maslo ispol'zovat'? Obsuždenie poleznosti, kulinarnyx pljusov. 2011)

(18) No, dorogoj moj, Darvin Darvinom, obez'jany obez'janami, a fakt nalico.

'Well my dear, we know about Darwin and the monkeys, but the fact is clear.'

(V. P. Kataev. Million terzanij. 1930) 


\subsection{Verbs}

In contrast to nouns, the NOM $\sim$ INS construction does not select for any particular verbs. The Pearson correlation between the frequency of verbs in our dataset compared to the overall frequency of verbs in the RNC is 0.97 , indicating that there is almost no difference between the use of verbs in the NOM $\sim$ INS construction and their distribution in general. An automatically generated semantic network of verbs in our dataset shows low density, confirming that these verbs show no specific tendencies.

However, verbs are worth examining because of the way verbs can motivate parts of the NOM INS construction. There are various options: a) the syntactic structure can motivate the use of a single grammatical case, b) the syntactic structure can motivate multiple grammatical cases, and c) the construction can appear in the absence of any syntactic structure that would motivate the use of the nominative or instrumental case. All of these situations, with various specifications, are relevant for the NOM INS construction.

\subsubsection{The nominative is motivated}

Some verb phrases require the nominative case, thus motivating only the first part of the $\mathrm{NOM} \sim$ INS construction. In example (19) the verb polučaetsja 'there obtains' can only be combined with a subject in the nominative case, so it is possible to drop the instrumental and get a well-formed sentence with just polučaetsja bardak 'there is a mess'. Similarly in (20), only the nominative is motivated as the predicate of a zero-copula (recall the discussion in Sect. 1), and it is again possible to delete the instrumental and say merely zemlja- $\underline{\text { suba }}$ 'the land is fertile'. However, in neither case is it possible to delete the nominative part of the NOM INS construction:

(19) Tak čto vmesto mifičeskoj vseob"emljuščej superbjurokratii polučaetsja bardak bardakom, orkestr s tremja dirižerami.

'So instead of a mythical all-encompassing super-bureaucracy we get a total mess, an orchestra with three conductors.'

(S. Jastrebov. Lunnaja sonata. 2007)

(20) Mužiki bogatye, a zemlja- ̌̌ba šuboj.

'The men are rich, and the land is very fertile.'

(D. N. Mamin-Sibirjak. Xleb. 1895)

Both examples like (19), in which the noun is the nominative subject of a clause, and examples like (20), in which it is a predicate noun, lend support to the NOM INS construction by motivating the nominative NP part of its structure.

\subsubsection{The instrumental is motivated}

Example (21) already has a nominative subject ( $o n$ 'he'), and the instrumental case is motivated as a metaphorical description of that subject and how 'he' looks at the speaker. In other words, it is possible to remove the nominative part of the NOM $\sim$ INS construction, leaving just the instrumental part, and retain a grammatical sentence with almost the same meaning: [...] on smotrel na menja baranom 'he was staring at me intently [lit. like a ram]'. This syntactic structure is part of the 'Label' use of the Russian instrumental (Janda 1993), and, like the nominative with subjects and predicate nouns, this syntactic structure is part of the web of supporting structures for the NOM INS construction:

(21) - I tak kak on smotrel na menja baran baranom [...].

'And because he was staring at me so stupidly ...'

(Ju. O. Dombrovskij. Obez’jana prixodit za svoim čerepom, čast' 3. 1943-1958) 


\subsubsection{Either the nominative or the instrumental is motivated}

When the verb is either byt' 'be' or another verb that can be used to indicate existence, such as a position verb, we have a syntactic structure that combines possible motivation of either the nominative or the instrumental, but not both. In (22), with a non-zero form of byt', one could elide either part of the NOM INS construction and still have a viable structure, either A do togo byla dura or A do togo byla duroj, both meaning 'And I was such a fool'. Similarly with respect to (23), one can produce either budete barin or budete barinom, both meaning 'you would be a nobleman'. It is crucial to note, however, that aside from the NOM INS construction, it is not possible to have both the nominative and the instrumental side-by-side in such syntactic structures. So while these syntactic structures support both parts of the NOM $\sim$ INS construction, they do not support the whole of the structure of the construction:

(22) A do togo byla dura duroj, ničego v Moskve ne ponimala... I srazu v artistki! 'And I was such an utter fool, I didn't understand anything in Moscow ... And right away I became an actress!'

(A. Pristavkin. Kukušata ili žalobnaja pesn' dlja uspokoenija serdca. 1992)

(23) Ešče by vam černuju šljapu s poljami, volosy dlinnye, kostjumčik modnyj naladit', trostočku, i budete barin-barinom.

'All that's missing would be for you to get a black hat with a brim, long hair, a fashionable suit, a cane, and you would be the ideal nobleman.'

(A. P. Čapygin. ¿̌emer. 1921)

\subsubsection{Constructions with the instrumental alongside the accusative}

An example like (24) follows the pattern of any transitive verb whose action can be carried out by means of an instrument, cf. rezat' mjaso nožom 'slice meat with a knife'. Both the accusative case (for a direct object) and the 'Means' use of the instrumental case (Janda 1993) are motivated by the syntactic structure. Although we technically have a different case here, accusative instead of nominative, the two cases are syncretic for the vast majority of nouns that could serve as both a direct object and an instrument, namely inanimate masculine and neuter nouns and feminine nouns ending in - $b$. Animate nouns are naturally excluded for semantic reasons (since an animate being is unlikely to serve as both the direct object and instrument in the same event), leaving the only possibility of non-homonymy of the nominative and accusative among feminine nouns ending in $-a /-j a:^{7}$

(24) No vam prosto neobxodimo vybit' klin klinom.

'Well you just have to fight fire with fire.'

(E. Belkina. Ot ljubvi do nenavisti. 2002)

\footnotetext{
${ }^{7}$ Examples of feminine $-a /-j a$ nouns in the Instrument use of NOM $\sim$ INS are rare and do not appear in our database, but can be found in the RNC, as illustrated here:

(i) Oni tože vbežali v dežurku, no lomat' silu siloj uže ne trebovalos': incident byl isčerpan, pri ètom nikogo ne ubili, čto redko byvaet.

'They also ran to the watchman's booth, but it was no longer necessary to stop force with force: the incident was over and no one was killed, which was unusual.'

(D. Koreckij. Menty ne angeli, no... 2011)

Notice that it is difficult to draw a line between examples in which the use of the accusative and instrumental cases is motivated by the valency of the verb and clear examples of the construction under scrutiny in the present study. However, in keeping with the principles of Construction Grammar, our aim is not to draw such a boundary. Instead, we suggest that examples like the one with silu siloj are related to the NOM $\sim$ INS construction insofar as the noun is repeated and occurs in the instrumental.
} 


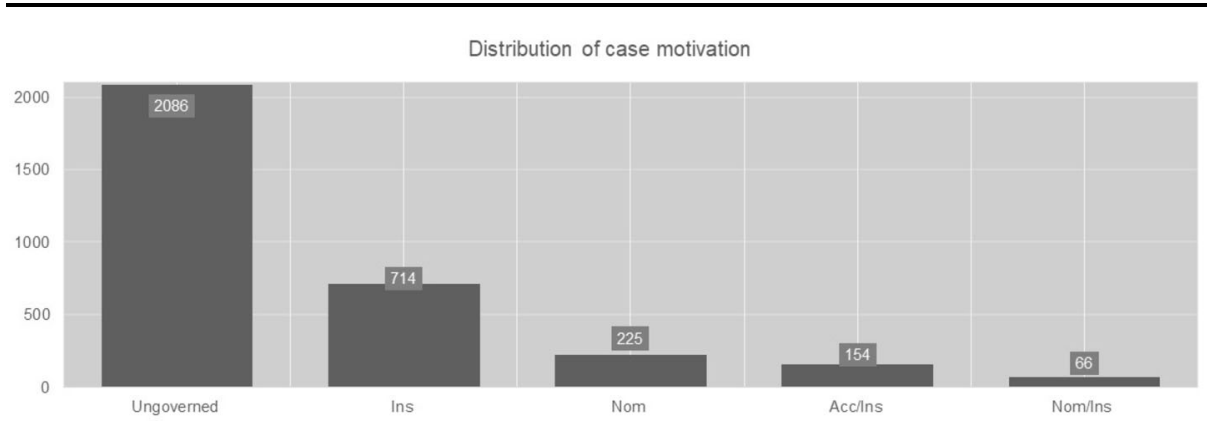

Fig. 1 Distribution of case motivation for our dataset

Acc/Ins = government of instrumental alongside accusative, Ins = government of instrumental, Nom $=$ government of nominative, Nom $/$ Ins $=$ government of either nominative or instrumental, Ungoverned $=$ no case government

While (24) is technically just a 'lookalike' with respect to the NOM INS construction, its relevance becomes stronger when we take into consideration examples in which klin klinom '(fight) fire with fire' has no syntactic context that could motivate the accusative case, as we see in example (26) below.

\subsubsection{Neither case is motivated}

The NOM INS construction can appear, in all of its meanings, syntactically devoid of any context that would clearly motivate either of its cases, as we see in (25) and (26). In such examples, the NOM $\sim$ INS construction has effectively broken away from all syntactic moorings and functions independently, evoking its meaning without any further contextual support:

(25) - Nu xorošo, rebjata, Artemka Artemkoj, a urok urokom...

'Ok, guys, we all know about Artemka, but now we have to study ...'

(V. Krapivin. Troe s ploščadi Karronad. 1979)

(26) Podobnye slučai opisany: spasajas' ili spasaja, ljudi čut' li ne po nitke preodolevali propasti: zdes' klin klinom.

'Similar cases have been described: when saving themselves or others, people avoided falling in an abyss by the skin of their teeth: here (you have to) fight fire with fire.'

(V. Levi. Iskusstvo byt' soboj. 1973)

Figure 1 displays the distribution of the five categories described in this subsection. The accusative + instrumental 'lookalike' type (Acc/Ins) and the ambiguous type in which either the nominative or instrumental are motivated (Nom/Ins) are both fairly marginal, and combined account for less than $7 \%$ of our data. Examples in which one case is motivated are robustly attested, but comprise only about $10 \%$ and about $20 \%$ of the data respectively. Over $60 \%$ of all examples are of the type in which neither case is motivated, meaning that for the most part the NOM INS construction operates on its own without any help from surrounding syntax.

\section{The radial category of core uses of the NOM INS construction}

In this section we revisit the three main subtypes of the NOM INS construction introduced in Sect. 1 and describe both a hybrid type and the structure of the core radial category of 
the construction. We emphasize the meanings of the construction and the semantic links that connect its subtypes, and on the basis of this analysis propose a radial category network for the core uses of the NOM INS construction in Sect. 3.4.

\subsection{Extreme}

The effect of the NOM INS construction in the Extreme meaning is to emphasize that an entity has some characteristic of the noun to an extreme degree. Aside from the highly lexicalized phrases čest' čest'ju and čin činom meaning 'properly' (cf. Sect. 2.1), most examples with this meaning describe human beings, usually in a negative way. However molodec molodcom 'extremely clever person' (cf. Sect. 2.1) emphasizes positive features, and the few other positive uses of the NOM INS construction tend to use words referring to people who are larger than life, such as nobility and heroes like bogatyr' 'hero-knight', knjaz' 'prince', and car' 'tsar', as in (27):

(27) - Byt' togo ne možet! Tot byl bogatyr' bogatyrem, a ètot... Net, ne on!

'That can't be! That guy was a real hero-knight, but this one ... No, not him!'

(G. M. Markov. Strogovy. Kn. 1. 1936-1948)

References to places and situations continue the focus on extremely negative characteristics in the Extreme meaning of the NOM INS construction, with words like ad 'hell' and dyra 'hole'. The Extreme meaning is also found in expressions involving darkness, such as ten' 'shadow' and noč' 'night', see (28) and (29):

(28) Ėtot maket (sejčas on v Muzee Izrailja) privlekal v Holyland religioznyx evreev iz SŠA, sama-to gostinica byla dyra dyroj.

'That architectural model (now in the Museum of Israel) attracted religious Jews from the USA to the Holy Land, but the hotel itself was the worst possible hole.'

(V. Bejder. Izbrali precedentom. Ogonek. 2014)

(29) Rebjatki prosnulis', prodrali glazenki-to, gljadjat: noč' noč ’ju.

'The guys woke up, opened their eyes, and they see: it is the darkest of nights.'

(V. G. Korolenko. Ubivec. 1882)

A vigorous action, such as marching, is also a candidate for the Extreme subtype, as in (30): ${ }^{8}$

(30) Čto vy segodnja tak zameškalis'? Marš maršem, Arsen Davidovič! Na vse desjat' desjatyx!

'Why are you so late today? March for all you're worth, Arsen Davidovič! Use all ten toes!'

(G. Adamov. Tajna dvux okeanov. 1939)

Huge size is a further option in the Extreme subtype, here with a metaphorical use of gora 'mountain' in (31), a meaning that is nearly contiguous with the partly obsolete peripheral subtype labeled 'Abundance' in Sect. 4:

(31) Čirknu spičkoj, ležit on gora goroj, lico s podušku, i glaz odin smotrit, - sam spit, a glaz smotrit...

'I strike a match, he's lying there like a huge mass, face down on the pillow, but looking with one eye, so he's sleeping but looking with one eye ...'

(A. S. Serafimovič. Myšinoe carstvo. 1913)

\footnotetext{
${ }^{8}$ In dictionaries, the syntactic category of marš is sometimes said to be particle or interjection, as in the command marš! 'forward!'. We will not discuss this question, but note that in the construction at hand the word combines with the instrumental case ending, and thus behaves like a noun.
} 


\subsection{Paragon}

The Paragon meaning of the NOM INS construction is closely related to the Extreme meaning, and can even be invoked by the same lexical items as we see with durak durakom which is interpreted as 'an absolute fool' in example (1), but as 'an ordinary fool' in (2). Indeed, some examples are ambiguous, allowing for both interpretations, as we see in (32). Example (32) illustrates a widespread property of the NOM $\sim$ INS construction when a comparison is involved - in this case with a blockhead:

(32) Zaenkov besnovalsja, Silaev, sidja bolvan bolvanom, raz za razom povtorjal odnu i tu že ošibku.

'Zaenkov was furious, Silaev was sitting there like the ultimate blockhead / like an ordinary blockhead, repeating the same error again and again.'

(A. Afinogenov. A vnizu byla zemlja. 1982)

Examples of the Paragon meaning tend to involve words that refer to items that lack a strong salient characteristic, and thus lexical choice is a factor in distinguishing Paragon from Extreme meanings. Again, we see that most examples involve characterizations of people, but for the Paragon meaning, the NOM $\sim$ INS construction describes people that fail to inspire interest. Here we observe words used to describe dull people, such as čučelo 'scarecrow', istukan 'dummy', čurban 'nitwit', as well as metaphorical uses of words for objects to refer to people with weak characteristics, like suxar' 'dry crust', pen' 'stump', peč' 'stove', trjapka 'rag', stolb 'pole', doska 'board' as in (33):

(33) Ne tak, mol, i durna, ne tak, mol, i glupa, nu nedotepa, nu bez ženskix dospexov doska doskoj.

'She's not, you know, so bad, not so stupid, just a goof, without any feminine qualities, just flat-chested.'

(G. Ščerbakova. Molenie o Eve. 2000)

In the Paragon meaning we also find generic terms for groups of people, such as those in (34)-(36):

(34) Ėti, dvadcatiletnie, byli togda v razgare boja za takoe ili edakoe iskusstvo, ja že ničego ne ponimala, sidela devčonka devčonkoj, slušala i terebila busy na šee... nitka razorvalas', busy pokatilis' vo vse storony.

'The twenty-somethings were all fired up to fight for some kind of art, but I didn't understand anything, I sat there as a little girl and listened, playing with my necklace ... the string broke and the beads scattered in all directions.'

(V. Katanjan. Lilja Brik. Žizn'. 1999)

(35) Batja byl nevysok rostom, korenast, so spiny - mužčina, a s lica - mal'čiška mal'čiškoj, kak budto emu bylo ne dvadcat' pjat', a let vosemnadcat'.

'The guy was short and stocky, from behind he was a man, but in his face he was just a boy, as if he wasn't twenty-five, but only about eighteen.'

(V. Mixal'skij. Dlja radosti nužny dvoe. 2005)

(36) Vyšel na solnce - i snova japonec japoncem, dostig polosy teni - i opjat' prevratilsja v pereodetogo pastuxa.

'When he walked out into the sunshine, he was an ordinary Japanese person, but when he stepped into the shade, again he turned into a person in shepherd's clothing.'

(E. Čižov. Perevod s podstročnika. 2012)

Common lexemes found in Paragon uses of the NOM INS construction are mass nouns referring to substances that are uninteresting (or not special given the context), like margarin 
'margarine', see (17) above, govno 'shit', soloma 'straw', trava 'grass', as in examples (37)(39):

(37) A obed - sup iz ovoščej i bol'še ničego. Konečno, voda-vodoj.

'And lunch was vegetable soup and nothing more. Of course it was just water.'

(S. A. Semenov. Golod. 1920-1929)

(38) Kisel' kiselem - amorfnaja massa [...].

'He's like a jellyfish, an amorphous mass ...'

(A. Izmajlov. Trjukač. 2001)

(39) Džoš zadumčivo posmotrel pod nogi. Steklo steklom. Navernoe, tol'ko v mikroskop možno razgljadet', iz čego že sdelana brejn-karta.

'Brooding, Josh looked down. It was just glass. One could probably make out what the brain-map was made of only with a microscope.'

(I. Naumov. Garlem - Detrojt. 2007)

Aside from references to people and substances, places as in (40) and abstractions as in (41) are occasionally observed in the Paragon meaning:

(40) A u Gogolja ego Gogolevo - selo selom, ego i na karte redko oboznačajut.

'And Gogol' has his Gogolevo-it's just a village, it's rarely marked on a map.'

(F. Krivin. Xvost pavlina. 1981-1987)

(41) Čto tut bylo-proisxodilo! Sperva šlo ničego, porjadok porjadkom.

'The things that happened here! At first it was nothing special, just ordinary order.'

(G. E. Nikolaeva. Bitva v puti. 1959)

\subsection{Discourse Change}

Closely related to the Paragon meaning is Discourse Change since it merely states that 'yes, $\mathrm{X}$ is what it is, but ...' In other words, Discourse Change, like Paragon, does not depend on exaggerating a pronounced characteristic, but merely acknowledging the ordinary characteristics of something, much like the Paragon example with kisel' 'jelly' in example (38) above.

The five most frequent instantiations of the Discourse Change meaning are listed in Table 1 in Sect. 2.1, where the extended subtype of Discourse Change, namely the NOM INS, a / no NOM INS construction is also described. Since discussions can be centered around any reference to anything, there are no restrictions on the choice of lexeme in the Discourse Change meaning, which even freely accepts proper nouns, as we see with Darvin 'Darwin' in example (18) and Artemka 'Artemka' in (25). Here we add to the observations made above two examples that illustrate variations in the use of conjunctions, namely the use of the conjunction $a$ 'and / but' in (42) and of $i$ 'and' in (43), in both cases to shift to a topic named in a full clause:

(42) No eda edoj, a v gnezde ešče i porjadok nado podderživat'.

'Well food is important, but one also has to keep the nest in order.'

(I. Koroleva. Pervyj šag vo vzrosluju žizn'. Nauka i žizn'. 2009)

(43) Sol' sol'ju, i vse že bez detalej ne obojtis'.

'Salt has its value, but you still can't ignore the details.'

(T. Bek. Ljudi-kaktusy-verbljudy, ili Dumaja ob Arsenii Tarkovskom (1997).

Družba narodov. 2003) 
Fig. 2 Radial category network for the core meanings of the NOM INS construction

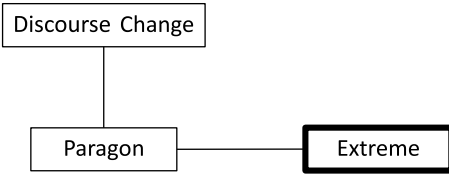

\subsection{Relationships among the core meanings of the NOM INS construction}

As argued above in Sects. 3.1-3.3, there are relationships among the meanings of the NOM INS construction. On the one hand, we observe a transition between the Extreme and the Paragon meanings since there are situations in which we cannot tell whether something is just rather ordinary or extremely dull and therefore ordinary, as in (32). We find a link between the Paragon and Discourse Change in that we establish the (ordinary) existence of one item in order to acknowledge it and then move on to another. We can thus propose the radial category network of the NOM INS construction depicted in Fig. 2, where we show the box around 'Extreme' in bold face to indicate the primacy of that meaning.

\section{Intensifying constructions and a close relative: stena stenoj 'a whole wall'}

The Extreme meaning and to some extent also the Paragon meaning of the NOM INS construction are part of a semantic family of constructions that express intensification (see Zhukova (2020) and data from the Russian Constructicon https://site.uit.no/russianconstructicon/), such as the bol'no Adv construction, as in bol'no xlopotno 'terribly troublesome', the nai-A-šij iz NP-Gen.Pl construction as in naimen'sij iz zol 'the least of the evils', and the do otkaza VP construction as in čemodan zabit do otkaza 'the suitcase is stuffed to capacity'.

The NOM INS construction has a marginal (less than $1 \%$ in our data, with all examples dated before 1945) use that signals intensity of quantity that we label 'Abundance'. Most instantiations of the construction involve lexemes that are used metaphorically to indicate large quantities such as stena 'wall', tuča 'cloud', t'ma 'darkness', and gory 'mountains', as in (44):

(44) Ja ešče zasomnevalsja sperva, potom smotrju - batjuški! Narodu krugom t'ma t'moj. 'At first I was skeptical, but then I see-oh my! There are so many people all around.'

(A. Truškin. 208 izbrannyx stranic. 1990-2002)

Though the Abundance use appears to be fading, we can consider it to be a peripheral member of the radial category of the NOM INS construction that is related to both the Extreme and Paragon meanings, which in the same way as Abundance imply that a property is present to a very high degree.

\section{Reduplication constructions and a next-of-kin relative: $k$ lin $k l i n o m$ '(fight) fire with fire'}

Reduplication constructions figure prominently in Russian: this classification in the Russian Constructicon is attested in over 80 constructions such as NP kak NP, as in nedelja kak nedelja 'a week like any other'. Reduplication constructions have attracted considerable scholarly attention (Iomdin 2013; Kopotev and Steksova 2016; Veličko 2016; Vilinbaxova and Kopotev 
2017; Apresjan 2018; Baranov and Dobrovol'skij 2019; Vilinbakhova and Escandell-Vidal 2019). ${ }^{9}$ It is furthermore the case that many Russian reduplication constructions have an intensifying meaning as well, such as the vse bez NP-Gen $i$ bez NP-Gen construction as in a my vse bez moloka i bez moloka 'and we are still without any milk at all', the Adj-preAdj construction as in dlinnyj-predlinnyj xvost 'an extremely long tail', and the NP-Nom VP-VP $i \mathrm{Cl}$ construction as in Ja ego prosil-prosil, $i$ on soglasilsja 'I begged him over and over, and he agreed'. Both the prominence of reduplication constructions in general and the salience of intensifying meaning among such constructions creates an environment that supports the NOM $\sim$ INS construction.

Reduplication and intensifying constructions also characterize the Instrument use, see klin klinom '(fight) fire with fire' in (9), (24), and (26) above, which we argue can be considered a 'next of kin' relative of the NOM INS construction. Example (45) illustrates the extent to which the Instrument use is multiply motivated and ambiguous in its relationship to governed uses of the instrumental case and the Extreme meaning of the NOM INS construction. This example juxtaposes an ordinary use of the instrumental case in vospitanie nakazaniem 'upbringing by means of punishment' with a 'relative' of the NOM INS construction: the Instrument use in vospitanie vospitaniem 'proper upbringing' that is free of any association with the accusative case and furthermore implies extreme measures. In view of the fact that Instrument uses tend to involve extreme measures, we consider Extreme its closest relative:

(45) A vtoroj poprosit, ubedit, ob"jasnit. Vospitanie nakazaniem i vospitanie vospitaniem. Vot dve vozmožnosti, dva varianta.

'And another person asks, makes a case, explains. There's upbringing by means of punishment and upbringing by means of upbringing / proper upbringing. There are these two possibilities, these two variants.'

(V. Amlinskij. Mal'čiški bez devčonok. Junost'. 1971)

On the basis of the close ties of the Abundance and the Instrument uses to the NOM INS construction we can posit that they are peripheral members of a network that we can diagram as shown in Fig. 3, in which dotted lines indicate the more tenuous relationships of the peripheral Abundance and Instrument members of the network to the core members. As mentioned above, Abundance is most closely associated with the Extreme and Paragon uses, since all three involve the presence of a property to a high degree. For Instrument, we regard Extreme as its closest relative, since Instrument often involves extreme measures, as illustrated in (45).

Fig. 3 Extended radial category network for the NOM INS construction

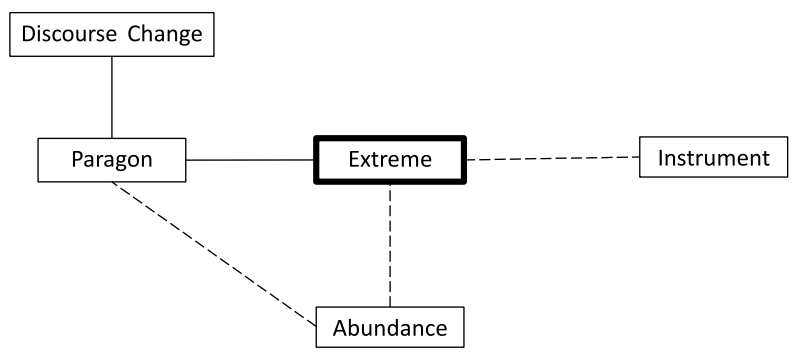

${ }^{9}$ Also Mel'čuk, I. Stat'ja kak stat'ja: pisat' tak pisat' (o sintaksičeskix idiomax) [manuscript]. 


\section{Generation shift}

Our data cover a period of over two centuries, and our semantic annotation makes it possible to track the relative frequencies of the various uses of the NOM INS construction across this time period, as displayed in Fig. 4.

The most important observations we can make from this distribution are that 1) the dominant uses of the NOM INS construction across all time periods are the Extreme and Discourse Change uses, and that 2) there has been a shift such that Extreme, which was dominant in the earlier period (1800-1949) has yielded to the Discourse Change use, which dominates the later period (1950-2018). In short, the center of gravity for the NOM INS construction has moved from Extreme to Discourse Change. This change is depicted in Fig. 5, with a boldfaced box around Discourse Change to indicate its new status as the dominant use of the NOM $\sim$ INS construction, and dotted lines around Extreme to indicate its loss of former status as the dominant use.

The governance patterns of the uses of the NOM INS construction (see Sect. 2.2 and Fig. 1) are relevant to the shift in dominance from the Extreme to the Discourse Change use. Whereas it is possible for all uses of the NOM INS construction to appear in contexts in which there is no governance of the nominative or instrumental case, such ungoverned uses predominate for Paragon and Discourse Change, and Discourse Change is over 99\% ungoverned. In other words, this historical shift is not only a semantic shift but also a shift in the relationship of the construction to context. The NOM INS construction has become dominated by the use that is most independent of surrounding syntax. This shift thus consolidates the status of the NOM $\sim$ INS construction as a unit in the language.

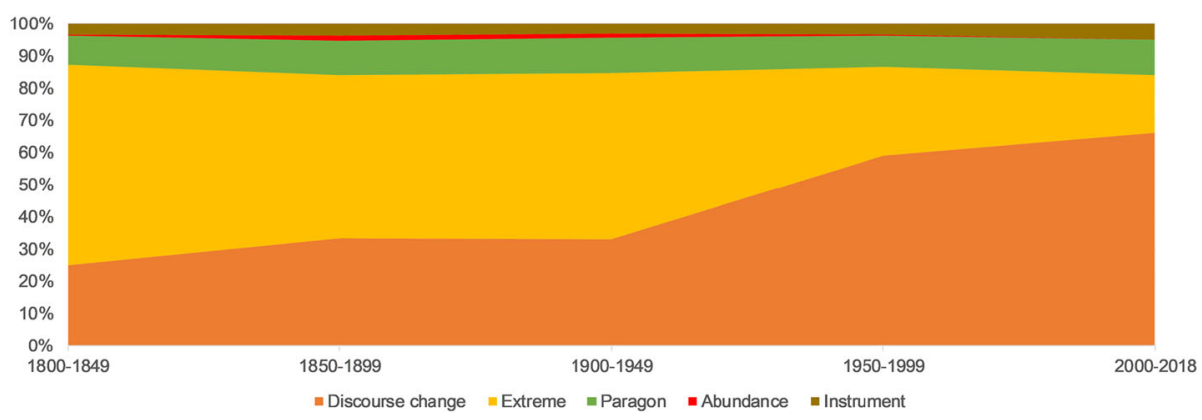

Fig. 4 Relative distribution of uses of the NOM $\sim$ INS construction over time

Fig. 5 Radial category network for the NOM $\sim$ INS construction indicating shift in dominance from Extreme to Discourse Change

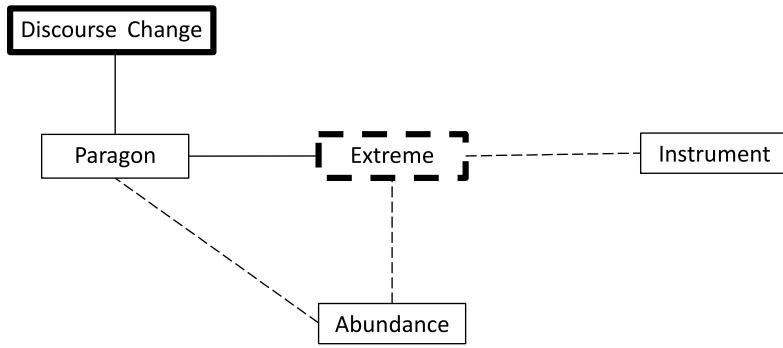




\section{Conclusion: the construction in its milieu}

The story of the NOM INS construction is a demonstration of the intricate and dynamic relationships between constructions and the grammatical structure of the language as a whole. We can diagram some of these relationships as in Fig. 6. Here we repeat the diagram in Fig. 5 showing the relationships between the different uses of the NOM INS construction, the position of peripheral vs. core uses, and the historical shift from the Extreme to the Discourse Change use. In addition, we overlay the presence of intensifying constructions and reduplication constructions as background facts from the structure of Russian. Reduplication constructions are relevant to all uses of the NOM $\sim$ INS construction, and extend well beyond it as well. In fact, many reduplication constructions utilize a similar semantic mechanism: they compare the signified of the $\mathrm{X}$ against an average $\mathrm{X}$; the comparison can refer to something greater than, less than, or equal to an average $\mathrm{X}$. The intensifying constructions intersect with reduplication constructions and include all Extreme and Abundance uses as well as a portion of Instrument and Paragon uses.

There are numerous other factors that contribute to the strong position of the NOM INS construction in Russian, but are not captured in Fig. 6. For example, there is the influence of verbal government in creating syntactic structures that partially or wholly reflect that of the NOM INS construction. The syncretism between nominative and accusative case forms for inanimate nouns interacts with verbal government to create structures that are homonymous with the NOM $\sim$ INS structure. Rhyme and entrenchment support the NOM $\sim$ INS construction in the case of idiomatic expressions like družba družboj, a služba služboj 'friendship is friendship, but service is service'. And the presence of drug drugom as part of the paradigm of the high frequency drug druga 'each other' construction is also a factor.

The NOM INS construction thus richly illustrates the tenets of Construction grammar stated in Sect. 1. We observe in detail how a network of related constructions behaves in the structure of a language as a whole. The interaction between the meanings of the nouns that collocate with this construction and the meaning of the construction as a whole demonstrates an interaction that is not entirely compositional. Examples of the NOM $\sim$ INS construction range from strongly lexicalized idioms such as čest' čest'ju 'properly' to more schematic

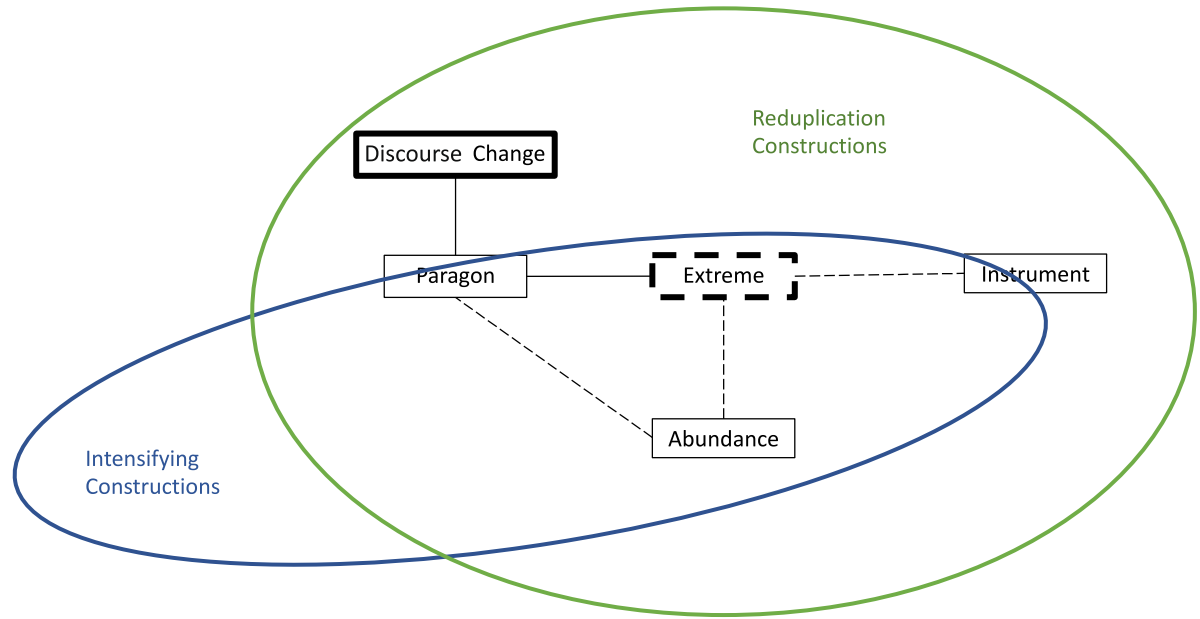

Fig. 6 Radial network of the NOM $\sim$ INS construction in relation to intensifying and reduplication constructions 
uses that can even include proper nouns, like Darvin Darvinom 'we know about Darwin' in example (18). And we see how the NOM INS construction has changed over time, with a shift from the Extreme use to the Discourse Change use which is also typically syntactically independent of its context.

Acknowledgements Open Access funding provided by UiT The Arctic University of Norway.

Publisher's Note Springer Nature remains neutral with regard to jurisdictional claims in published maps and institutional affiliations.

Open Access This article is licensed under a Creative Commons Attribution 4.0 International License, which permits use, sharing, adaptation, distribution and reproduction in any medium or format, as long as you give appropriate credit to the original author(s) and the source, provide a link to the Creative Commons licence, and indicate if changes were made. The images or other third party material in this article are included in the article's Creative Commons licence, unless indicated otherwise in a credit line to the material. If material is not included in the article's Creative Commons licence and your intended use is not permitted by statutory regulation or exceeds the permitted use, you will need to obtain permission directly from the copyright holder. To view a copy of this licence, visit http://creativecommons.org/licenses/by/4.0/.

\section{References}

Apresjan, V. (2018). Russian constructions with syntactic reduplication of colour terms: A corpus study. Russian Journal of Linguistics, 22(3), 653-674. https://doi.org/10.22363/2312-9182-2018-22-3-653-674.

Baranov, A. N., \& Dobrovol'skij, D. O. (2019). Idiomatičnost' dubletnyx form. Voprosy jazykoznanija, 6, 51-67.

Croft, W. (2001). Radical Construction Grammar. Syntactic theory in typological perspective. Oxford.

Diessel, H. (2015). Usage-based construction grammar. In E. Dąbrowska \& D. Divjak (Eds.), Handbook of cognitive linguistics (Vol. 39, pp. 296-322). Berlin.

Fried, M., \& Östman, J.-O. (2004). Construction Grammar: A thumbnail sketch. In M. Fried \& J.-O. Östman (Eds.), Construction Grammar in a cross-language perspective (Constructional Approaches to Language, 2, pp. 11-86). Amsterdam, Philadelphia.

Goldberg, A. (1995). Constructions. A Construction Grammar approach to argument structure. Chicago.

Goldberg, A. (2005). Constructions at work. The nature of generalization in language. Oxford.

Gries, S. T. (2011). Phonological similarity in multi-word units. Cognitive Linguistics, 22(3), 491-510.

Iomdin, L. L. (2013). Čitat' ne čital, no ...: ob odnoj russkoj konstrukcii s povtorjajuščimisja slovesnymi èlementami. In V. P. Selegej (Ed.), Komp'juternaja lingvistika i intellektual'nye texnologii 12(1), 297310.

Janda, L. A. (1993). A geography of case semantics: The Czech dative and the Russian instrumental (Cognitive Linguistics Research, 4). Berlin.

Knjazev, Ju. P. (2007). Reciprocal constructions in Russian. In V. P. Nedjalkov (Ed.), Reciprocal constructions, Vol. 2 (Typological Studies in Language, 71, pp. 673-708). Amsterdam, Philadelphia.

Kopotev, M. V., \& Steksova, T. I. (2016). Isključenie kak pravilo. Moskva.

Langacker, R. W. (2008). Cognitive Grammar. A basic introduction. Oxford.

Mathiassen, T. (1996). Russisk grammatikk. Oslo.

Moser, M. (1994). Der prädikative Instrumental (Europäische Hochschulschriften. European University Studies. Publications Universitaires Européennes, 45: Slawische Sprachen und Literaturen). Frankfurt.

Mrazek, R. (1964). Sintaksis russkogo tvoritel'nogo (Opera universitatis purkynianae brunensis facultas philosophica, 94). Praha.

Nichols, J. (1981). Predicate nominals: a partial surface syntax of Russian (University of California Publications in Linguistics, 97). Los Angeles, London.

Veličko, A. V. (2016). Predloženija frazeologizirovannoj struktury v russkom jazyke. Moskva.

Vilinbaxova, E. L., \& Kopotev, M. V. (2017). «X est' X» značit «X èto X»? Iščem otvet v sinxronii i diaxronii. Voprosy jazykoznanija, 3, 110-124.

Vilinbakhova, E., \& Escandell-Vidal, V. (2019). "People are people to me": The interpretation of tautologies with frame-setters. Journal of Pragmatics, 143, 96-108.

Zhukova, V. (2020). Intensifying constructions in Russian based on data from Russian Constructicon (MA thesis, National Research University Higher School of Economics). Moscow. 